\title{
Manfaat Pemberian ASI Eksklusif dalam Pencegahan Kejadian Dermatitis Atopi pada Anak
}

\author{
Anita Halim, Zakiudin Munasir, Rinawati Rohsiswatmo \\ Departemen Ilmu Kesehatan Anak Fakultas Kedokteran Universitas Indonesia-Rumah Sakit Cipto \\ Mangunkusumo, Jakarta
}

\begin{abstract}
Latar belakang. Dermatitis atopi merupakan manifestasi penyakit alergi yang sering terjadi pada anak. Prevalens dermatitis atopi (DA) meningkat di seluruh dunia dengan awitan tersering pada usia 1 tahun pertama, cenderung relaps, dan diikuti allergic march hingga dewasa. Peran ASI dalam mencegah DA masih kontroversi. Studi mengenai hal ini belum banyak dilakukan di Indonesia.

Tujuan. Mengetahui manfaat pemberian ASI eksklusif dalam mencegah DA pada anak.

Metode. Desain kasus kontrol berpasangan dengan matching usia dan riwayat atopi keluarga

Hasil. Limapuluh empat pasang subjek kasus-kontrol berusia 7-24 bulan ikut serta dalam penelitian. Sebagian besar kelompok kasus berusia 7-12 bulan, memiliki atopi keluarga, dengan awitan tersering pada usia 6 bulan pertama, dan predileksi pada wajah. Tidak terdapat perbedaan pola dan lama menyusui pada kelompok kasus dan kontrol. Manfaat ASI dalam mencegah DA pada anak belum terbukti (RO 0,867; IK95\% 0,512-2,635; p 0,851).

Kesimpulan. Penelitian ini belum dapat membuktikan manfaat pemberian ASI eksklusif untuk mencegah DA pada anak. Sari Pediatri 2014;15(6):345-52.
\end{abstract}

Kata kunci: dermatitis atopi, ASI eksklusif

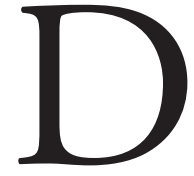

ermatitis atopi (DA) adalah kelainan inflamasi kronis pada kulit yang sering terjadi pada anak. Masalah ini menjadi semakin penting karena prevalens yang

\footnotetext{
Alamat korespondensi:

DR. Dr. Zakiudin Munasir, SpA(K). Departemen Ilmu Kesehatan Anak Fakultas Kedokteran Universitas Indonesia-Rumah Sakit Cipto Mangunkusumo. Jl. Diponegoro 71. Telp. (021) 3161144, Fax. 0213907743 E-mail:zakiudin_munasir@idai.or.id; dranita_halim@yahoo.com
}

meningkat di seluruh dunia. ${ }^{1-5}$ Prevalens DA pada anak meningkat 2-3 kali selama tiga dekade terakhir terutama di negara maju, seperti di Amerika Serikat, Jepang, dan negara-negara di Eropa Barat (10\%-20\%). ${ }^{3-9}$ Prevalens DA yang lebih rendah terdapat pada negara berkembang di Eropa Timur, Afrika, dan Asia Tengah. ${ }^{3,5,10}$ Sebuah studi kohort di Jakarta pada tahun 2010 dilaporkan prevalens DA $16,4 \%$ pada anak berusia 0-6 bulan. ${ }^{11}$ Sekitar $80 \%$ anak dengan DA akan mengalami asma dan rinitis alergi (allergic march) di kemudian hari. ${ }^{12,13}$ 
Dermatitis atopi menimbulkan morbiditas pada anak berupa kesulitan tidur, iritabilitas, gangguan pola makan, gangguan pertumbuhan, dan konsentrasi. Pada orangtua, mengasuh anak dengan DA mengakibatkan gangguan tidur, kecemasan dan depresi pada orang tua, serta menambah beban ekonomi keluarga. ${ }^{1,2,14}$

Lesi DA memiliki predileksi lokasi dan morfologi yang khas sesuai dengan usia. ${ }^{1,3,15}$ Dermatitis atopi tipe infantil terjadi pada usia 0-2 tahun, dengan predileksi pada wajah (pipi) atau di area ekstensor ekstremitas pada bayi berusia di atas 10 bulan. Lesi bersifat lembab dengan eksudat. Dermatitis atopi tipe anak terjadi pada usia 2-12 tahun, dengan predileksi pada fleksor ekstremitas. Lesi kering dengan gambaran papul dan likenifikasi. Dermatitis atopi tipe remaja/dewasa ditandai gatal dan likenifikasi hebat, dengan predileksi mirip DA tipe anak. Lesi yang luas di luar tempat-tempat predileksi dapat terjadi pada kasus berat. ${ }^{1,3}$

Dermatitis atopi merupakan reaksi alergi yang sebagian besar termasuk dalam reaksi hipersensitivitas tipe I. ${ }^{4,16,17}$ Beberapa konsep yang penting dalam terjadinya DA, yaitu kerentanan genetik, faktor lingkungan, defek fungsi barier kulit, dan respon imun lokal maupun sistemik. ${ }^{18-20}$ Pada jaringan kulit individu dengan DA terdapat lebih banyak sitokin sel T-helper 2 (Th2) yaitu interleukin-4 (IL4) dan IL-13 yang menginduksi sintesis IgE spesifik terhadap alergen. Imunoglobulin E berada dalam sirkulasi dan sebagian berikatan dengan sel mast dan sel Langerhans di jaringan kulit. Pada pajanan berulang, alergen akan berikatan dengan $\operatorname{IgE}$ pada sel mast dan Langerhans, diikuti pelepasan mediator dan sitokin Th2 yang berperan lesi akut. ${ }^{4,18,19}$ Pada lesi kronik, terjadi infiltrasi sel dendrit, makrofag dan eosinofil, produksi sitokin IL-12 serta terbentuk $\mathrm{Th}_{1}$ dan interferon- $\gamma($ IFN $-\gamma)$, yang berperan dalam remodeling kulit. ${ }^{4,19}$

Diagnosis DA ditegakkan secara klinis. Salah satu kriteria diagnosis yang sering digunakan untuk kepentingan klinis maupun epidemiologis, dan yang digunakan dalam penelitian ini adalah kriteria HanifinRajka. ${ }^{21,22}$ Pemeriksaan laboratorium dan uji kulit dapat dilakukan sebagai pemeriksaan penunjang, tetapi tidak memastikan diagnosis DA. ${ }^{1,3,19}$

Etiologi DA belum diketahui, tetapi risiko terjadi DA pada seorang anak dipengaruhi oleh beberapa faktor, yaitu usia, genetik, lingkungan, dan diet. Kelompok usia yang paling berisiko mengalami DA adalah kelompok usia $0-12$ bulan (60\% kasus) dengan awitan tersering pada usia 2-3 bulan. Riwayat atopi pada keluarga (ayah, ibu, atau saudara kandung) merupakan faktor risiko terpenting terjadinya DA. ${ }^{1,3,4,6,10,14}$ Risiko DA pada anak yang salah satu orang tuanya memiliki riwayat DA 60\%, dan meningkat menjadi $80 \%$ apabila kedua orang tuanya memiliki riwayat DA. ${ }^{3}$ Lingkungan dan diet merupakan sumber alergen yang menjadi pencetus DA. ${ }^{23,24}$ Kejadian alergi makanan yang dibuktikan dengan uji eliminasi provokasi, didapatkan pada 33\%-63\% anak dengan DA. ${ }^{19}$ Anak dengan alergi makanan memiliki risiko 2-4 kali lebih besar mengalami DA dibandingkan anak yang tidak mengalami alergi makanan. Alergi protein susu sapi menjadi pencetus $45 \%$ DA pada bayi. ${ }^{23}$

Studi kohort berskala besar oleh Grulee $\mathrm{dkk}^{25}$ melaporkan peningkatan risiko DA tujuh kali lebih besar pada bayi yang mendapat susu formula dibandingkan dengan bayi yang mendapat ASI. Sejak itu, banyak penelitian yang dilakukan untuk membuktikan hipotesis ini, tetapi hasilnya masih kontroversi. Belum banyak studi yang meneliti hubungan antara pemberian ASI eksklusif dengan kejadian DA di Indonesia. Munasir $\mathrm{dkk}^{11}$ melakukan studi kohort selama 6 bulan terhadap bayi baru lahir di Jakarta belum berhasil menyimpulkan peran pajanan makanan hiperalergenik, pemberian ASI, pajanan asap rokok dan debu di lingkungan sebagai faktor risiko DA pada bayi berusia 0-6 bulan. Studi potong lintang oleh Djunaedi, ${ }^{26}$ di Bandung, disimpulkan pemberian ASI eksklusif selama minimal 4 bulan dapat mencegah terjadinya DA.

\section{Metode}

Penelitian kasus kontrol berpasangan yang bertujuan untuk mengetahui manfaat pemberian ASI eksklusif terhadap pencegahan kejadian DA pada anak. Penelitian dilakukan di Poliklinik IKA RSIA Hermina Podomoro, RSIA Evasari, dan sebuah Posyandu di Jakarta, pada bulan Juli hingga Desember 2012. Sampel penelitian diambil secara consecutive sampling. Subjek dalam kelompok kasus adalah anak berusia 7-24 bulan dengan lesi kulit sesuai DA berdasarkan kriteria Hanifin-Rajka. Pada tempat dan waktu yang sama, diambil kontrol yaitu anak yang tidak pernah mengalami DA, dengan matching kelompok usia dan ada/tidaknya riwayat atopi keluarga. Anak adopsi, anak yang karena kondisi tertentu tidak mendapat ASI 
dari ibunya (seperti anak dari ibu dengan HIV/AIDS, anak dari ibu dengan keganasan payudara, dan anak dengan kelainan kongenital yang dapat memengaruhi respon imun (seperti Sindrom Down) dieksklusi dalam penelitian ini. Riwayat atopi keluarga dinyatakan ada apabila terdapat riwayat penyakit alergi (asma, rinitis alergi, dermatitis atopi, dan alergi makanan) pada ayah, ibu atau saudara kandung. ASI eksklusif adalah konsumsi ASI saja sejak bayi dilahirkan sampai berusia 6 bulan. Data diolah dengan menggunakan program SPSS versi 16. Persetujuan penelitian diberikan oleh Komisi Etik Penelitian Fakultas Kedokteran Universitas Indonesia. Persetujuan mengikuti penelitian diberikan oleh orangtua setelah diberikan penjelasan mengenai penelitian.

\section{Hasil}

Terdapat 57 subjek yang memenuhi kriteria sebagai subjek dalam kelompok kasus, tetapi 3 di antaranya dieksklusi ( 1 anak adopsi, dan 2 karena orang tua tidak ingat jelas riwayat pemberian ASI) sehingga dianalisis 54 pasang kasus-kontrol. Karakteristik subjek penelitin tertera pada Tabel 1. Status ekonomi keluarga sebagian besar berada di atas garis kemiskinan dengan median pendapatan per kapita per bulan Rp 1.600.000,00 (range Rp300.000,00 - Rp10.000.000,00). Tidak terdapat perbedaan usia ibu, pendidikan ibu, status ekonomi keluarga, dan pola pemberian ASI pada kelompok kasus dan kontrol. Pemberian ASI eksklusif didapatkan pada 38,9\% subjek. Durasi pemberian

Tabel 1. Karakteristik subjek penelitian $(\mathrm{N}=108)$

\begin{tabular}{|c|c|c|c|}
\hline Karakteristik & Kelompok kasus & Kelompok kontrol & Jumlah (\%) \\
\hline \multicolumn{4}{|l|}{ Jenis kelamin } \\
\hline Laki-laki & 30 & 25 & $55(51)$ \\
\hline Perempuan & 24 & 29 & $53(49)$ \\
\hline \multicolumn{4}{|l|}{ Kelompok usia (bulan) } \\
\hline $7-12$ & 27 & 27 & $54(50)$ \\
\hline $13-18$ & 13 & 13 & $26(24)$ \\
\hline $19-24$ & 14 & 14 & $28(26)$ \\
\hline \multicolumn{4}{|l|}{ Riwayat atopi keluarga } \\
\hline Ada & 36 & 36 & $72(66,7)$ \\
\hline Tidak ada & 18 & 18 & $36(33,3)$ \\
\hline \multicolumn{4}{|l|}{ Usia ibu (tahun) } \\
\hline$<25$ & 13 & 6 & $19(17,6)$ \\
\hline $25-35$ & 40 & 42 & $82(75,9)$ \\
\hline$>35$ & 1 & 6 & $7(6,5)$ \\
\hline \multicolumn{4}{|l|}{ Pendidikan ibu } \\
\hline Rendah & 4 & 1 & $5(4,6)$ \\
\hline Tinggi & 50 & 53 & $103(95,4)$ \\
\hline \multicolumn{4}{|l|}{ Status ekonomi keluarga } \\
\hline Di bawah garis kemiskinan & 2 & 0 & $2(1,9)$ \\
\hline \multicolumn{4}{|l|}{ Pola pemberian ASI } \\
\hline Sama sekali tidak mendapat ASI & 2 & 1 & $3(2,8)$ \\
\hline \multicolumn{4}{|l|}{ ASI non-eksklusif } \\
\hline - ASI dan formula sejak lahir & 21 & 20 & $41(37,9)$ \\
\hline - ASI saja hingga usia <4 bulan & 6 & 6 & $12(11,1)$ \\
\hline - ASI saja hingga usia 4-5 bulan & 5 & 5 & $10(9,3)$ \\
\hline ASI eksklusif 6 bulan atau lebih & 20 & 22 & $42(38,9)$ \\
\hline \multicolumn{4}{|l|}{ Durasi pemberian ASI (bulan) } \\
\hline Median (minimum; maksimum)* & $6(0 ; 21)$ & $7(0 ; 23)$ & \\
\hline
\end{tabular}

*uji Wilcoxon untuk data non-parametrik, $\mathrm{p}=0,073$; nilai $\mathrm{p}$ bermakna jika $<0,05$ 
Tabel 2. Karakteristik dermatitis atopi ( $\mathrm{N}=54$ subjek)

\begin{tabular}{ll}
\hline Karakteristik & Jumlah (\%) \\
\hline Jenis kelamin & \\
$\quad$ Laki-laki & $30(55)$ \\
$\quad$ Perempuan & $24(45)$ \\
Awitan terjadinya DA bulan & \\
$0-6$ & $32(59,3)$ \\
$7-12$ & $14(25,9)$ \\
$13-18$ & $6(11,1)$ \\
$19-24$ & $2(3,7)$ \\
Lokasi lesi & \\
Wajah (pipi) & $41(75,9)$ \\
Lipat siku & $5(9,3)$ \\
Lipat lutut & $1(1,9)$ \\
Lebih dari 1 lokasi & $7(12,9)$ \\
\hline
\end{tabular}

DA (Tabel 3). Analisis stratifikasi dilakukan untuk melihat satu per satu hubungan pemberian ASI eksklusif dengan kejadian DA pada anak yang memiliki riwayat atopi keluarga dan yang tidak memiliki riwayat atopi keluarga (Tabel 4). Pada anak dengan riwayat atopi pada keluarga didapatkan bahwa ASI menjadi cenderung menjadi faktor protektif terjadinya DA, sebaliknya pada anak tanpa atopi keluarga ASI dapat menjadi faktor risiko DA, tetapi keduanya tidak bermakna secara statistik.

\section{Pembahasan}

Sebagian besar subjek berada dalam kelompok usia 7-12 bulan dan memiliki riwayat atopi keluarga. Hal

Tabel 3. Hubungan pemberian ASI eksklusif dengan kejadian DA ( $\mathrm{N}=54$ pasang)

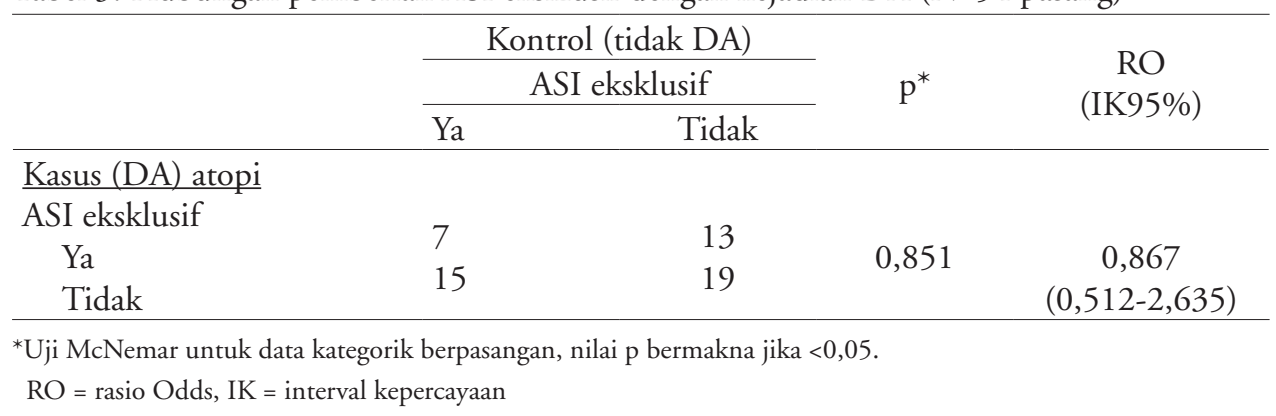

Tabel 4. Hubungan pemberian asi eksklusif dengan kejadian DA pada subjek dengan atopi keluarga ( $\mathrm{N}=36$ pasang) dan tanpa atopi keluarga ( $\mathrm{N}=18$ pasang)

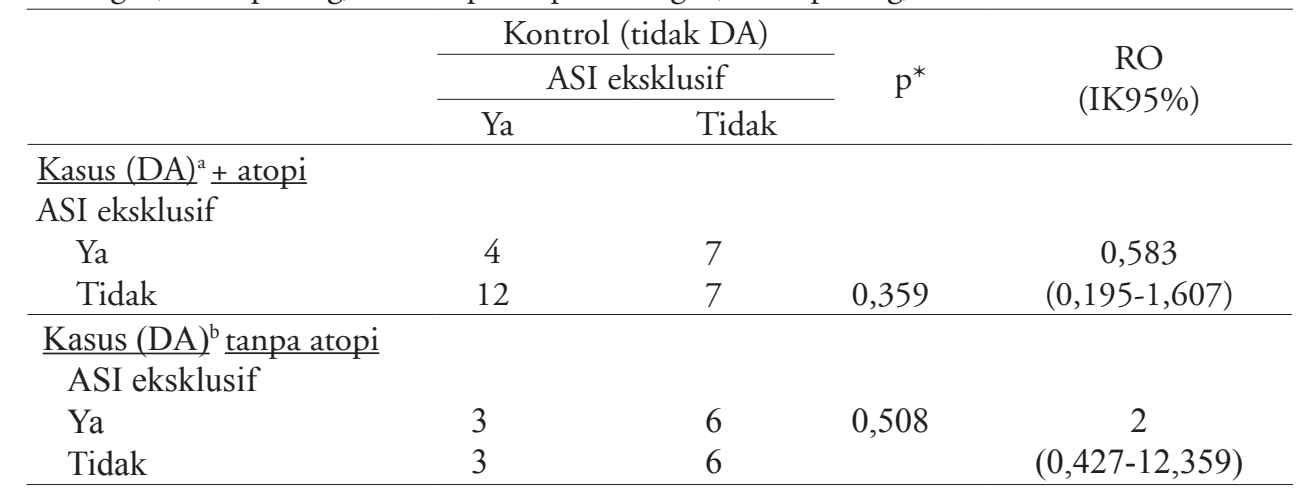

Keterangan: $\mathrm{a}=$ kelompok subjek dengan atopi keluarga, $\mathrm{b}=$ kelompok subjek tanpa atopi keluarga, ${ }^{*}=\mathrm{Uji}$ McNemar untuk data kategorik berpasangan, nilai p bermakna jika $<0,05$.

ASI pada kelompok kontrol lebih lama dibandingkan kelompok kasus, tetapi tidak bermakna secara statistik $(\mathrm{p}=0,073)$.

Penelitian ini belum dapat membuktikan adanya manfaat pemberian ASI eskslusif untuk mencegah tersebut terjadi karena pengambilan subjek berawal dari pemilihan kelompok kasus. Sebagian besar ibu berada pada usia reproduktif yang baik, berpendidikan tinggi, dan memiliki status ekonomi baik karena mayoritas subjek diambil dari poliklinik RS swasta dan Posyandu di lingkungan kelas menengah ke atas di 
Jakarta. Peneliti memilih tempat penelitian pada kelas ekonomi menengah ke atas karena diharapkan lebih cepat memperoleh subjek penelitian dan diketahui insidens DA lebih tinggi didapatkan pada kelompok sosial ekonomi tinggi. ${ }^{1,10}$

Pada kelompok kasus tidak didapatkan perbedaan proporsi kejadian DA pada anak laki-laki dan perempuan. Lokasi tersering DA adalah pada wajah, dengan awitan terbanyak pada usia 6 bulan pertama. Hal tersebut sesuai hasil studi epidemiologi DA sebelumnya, bahwa tidak ada perbedaan risiko DA berdasarkan jenis kelamin dan predileksi DA pada anak berusia usia 0-2 tahun tersering adalah pada wajah. Beberapa pendapat mengenai lokasi DA tersering pada wajah (pipi) karena sering berkontak langsung dengan alergen makanan yang mungkin terdapat dalam ASI atau susu formula saat bayi menyusu. Awitan DA tersering pada usia 6 bulan pertama berkaitan dengan keseimbangan sitokin yang cenderung ke arah $\mathrm{Th}_{2}$ pada saat bayi dalam kandungan dan awal kehidupan. ${ }^{18}$

Pemberian ASI eksklusif selama 6 bulan didapatkan pada 42 subjek (38,8\%). Serupa dengan hasil penelitian sebelumnya di Jakarta dan data Survei Demografi Kesehatan Indonesia (SDKI) tahun 2007 yang mendapatkan prevalensi pemberian ASI eksklusif berturut-turut adalah 33,2\% dan 32\%. ${ }^{11} \mathrm{Pada}$ penelitian kami, rerata lama pemberian ASI pada kelompok kontrol 1 bulan lebih lama dibandingkan kelompok kasus, tetapi tidak bermakna secara statistik. Beberapa alasan dipaparkan oleh ibu yang tidak memberikan ASI eksklusif, di antaranya produksi ASI sedikit, kecemasan bahwa bayi akan kelaparan dan kekurangan cairan, anak sempat didiagnosis kuning, dan ibu mulai bekerja saat anak berusia 2 bulan dengan ASI perah yang disimpan tidak cukup.

Air susu ibu merupakan nutrisi terbaik untuk bayi. Selain memenuhi kebutuhan nutrisi, ASI juga berperan dalam pembentukan kekebalan tubuh dan pencegahan penyakit alergi. ${ }^{27,28}$ Imunoglobulin A sekretorik (sIgA) yang terdapat dalam ASI akan bertahan dalam saluran cerna dan mencegah melekatnya alergen/ kuman patogen pada dinding saluran cerna. Berbagai senyawa lain dalam ASI seperti laktoferin, lisozim, oligosakarida, musin, dan interferon, memengaruhi kolonisasi mikroflora, meningkatkan maturasi mukosa usus dan respon imun humoral, serta memodulasi sistem imun ke arah $\mathrm{Th}_{1}$ sehingga mengurangi risiko kejadian alergi. ${ }^{28-32}$ Sel makrofag, limfosit, dan polimorfonuklear yang banyak terdapat dalam kolostrum, bersama dengan sel epitel pada kelenjar payudara memproduksi senyawa seperti transforming growth factor-alpha $(T G F-\alpha)$, transforming growth factor-beta (TGF- $\beta$ ), dan interleukin. Senyawa TGF- $\beta$ berperan dalam pembentukan kekebalan tubuh melalui peningkatan kemampuan bayi menyintesis sIgA sebagai respon terhadap antigen yang masuk lewat makanan.

Kalliomaki $\mathrm{dkk}^{34}$ memaparkan 2 teori tentang mekanisme ASI dalam mencegah DA, yaitu toleransi oral dan penundaan sensitisasi dini. ${ }^{33}$ Berbagai antigen makanan ditemukan dalam ASI, berkaitan dengan diet ibu. Antigen dalam jumlah kecil ini berikatan dengan antibodi spesifik dari ASI, menimbulkan efek protektif dengan cara menginduksi reaksi yang toleran terhadap antigen tersebut, yang disebut dengan toleransi oral..$^{35}$ Penundaan sensitisasi dini terjadi melalui adanya sIgA di mukosa usus bayi yang menghalangi masuknya antigen ke mukosa, dan secara tidak langsung terjadi pada pemberian ASI eksklusif selama 6 bulan.

Sejumlah penelitian ilmiah berusaha untuk membuktikan peran ASI dalam mencegah kejadian DA, tetapi hasilnya masih kontroversi. Penelitian kohort prospektif oleh Kull dkk ${ }^{36}$ menunjukkan bahwa pemberian ASI eksklusif selama minimal 4 bulan dapat mengurangi risiko terjadinya DA dan asma sampai usia 4 tahun pertama. Efek protektif ASI terhadap DA juga ditemukan pada beberapa penelitian lainnya. ${ }^{26,37-44} \mathrm{Di}$ lain pihak, beberapa studi melaporkan bahwa ASI tidak memengaruhi risiko terjadinya $\mathrm{DA}^{45,46}$ atau bahkan berkaitan dengan meningkatnya risiko DA. ${ }^{15,47-49}$

Kami belum berhasil membuktikan peran pemberian ASI eksklusif untuk mencegah kejadian DA pada anak berusia 7-24 bulan. Kami juga mendapatkan bahwa ASI eksklusif pada anak yang memiliki riwayat atopi keluarga cenderung menjadi faktor protektif terjadinya DA, sebaliknya dapat menjadi faktor risiko terjadinya DA pada anak tanpa riwayat atopi pada keluarga, tetapi keduanya tidak bermakna. Hasil penelitian kami sesuai dengan hasil penelitian yang dilakukan Ludvigson $\mathrm{dkk}^{45}$ yang melaporkan pemberian ASI eksklusif tidak memengaruhi risiko terjadinya DA. Miyake $\mathrm{dkk}^{7}$ dan Pohlabeln $\mathrm{dkk}^{50}$ dalam studinya mendapatkan ASI eksklusif sebagai faktor risiko DA pada anak tanpa riwayat atopi pada keluarga. Efek proteksi ASI terhadap DA pada keluarga dengan riwayat atopi dilaporkan dalam metaanalisis terhadap 18 studi prospekif oleh Gdavelich dkk. ${ }^{12}$ Dualisme efek ASI yaitu sebagai faktor risiko DA pada bayi tanpa atopi keluarga, dan memberi efek proteksi DA 
pada bayi dengan atopi keluarga juga dilaporkan oleh Siltanen dkk. ${ }^{51}$

Penelitian kami belum dapat membuktikan peran ASI dalam mencegah DA. Hal tersebut terjadi karena terdapat faktor risiko lain yang diperkirakan dapat memengaruhi kejadian DA yang tidak dikendalikan. Dua faktor risiko utama yaitu usia dan riwayat atopi pada keluarga sudah disingkirkan dengan metode matching. Faktor perancu lain seperti pajanan asam rokok, pajanan debu rumah dan tungau debu rumah, kekerapan infeksi, cara persalinan, pemberian probiotik saat ibu hamil atau setelah bayi lahir tidak dibahas dalam penelitian ini. Faktor pencetus DA yang lain seperti alergen inhalan tidak masuk dalam lingkup penelitian sehingga DA pada anak yang dietnya sudah diintervensi dengan pemberian ASI eksklusif masih dapat mengalami DA. Telaah kritis studi terdahulu lebih sering memberikan hasil yang mendukung adanya efek proteksi ASI dalam mencegah DA, tetapi telaah studi terbaru memberikan efek proteksi yang lebih lemah dan kurang bermakna secara statistik. Hal tersebut memperkuat dugaan adanya faktor lingkungan yang berperan dalam kejadian alergi. Hasil yang tidak bermakna juga mungkin disebabkan adanya reverse-causality effect. Ibu dengan riwayat atopi dan pengetahuan yang baik akan menyadari bayi memiliki risiko tinggi mengalami DA sehingga akan memberikan ASI eksklusif dan dengan durasi yang lebih lama. Peningkatan kejadian DA pada anak yang mendapatkan ASI ekslusif dikaitkan dengan kejadian infeksi saluran napas atas yang lebih rendah. ${ }^{52}$

Kompenen alergen dan imunologi dalam ASI juga berbeda antar individu berkaitan dengan faktor genetik dan diet ibu. Diet ibu terhadap bahan makanan hiperalergenik (seperti susu sapi, telur, kacang, dan makanan laut) tidak diintervensi. Kandungan sIgA, TGF- $\beta 2$ dan asam lemak tidak jenuh rantai ganda dalam ASI ibu dengan atopi lebih rendah dibandingkan ibu tanpa riwayat atopi. ${ }^{35,53-56}$ Adanya kontroversi antara studi yang satu dengan lainnya disebabkan juga adanya perbedaan desain penelitian, perbedaan kriteria diagnosis DA, randomisasi, dan blinding. ${ }^{42}$

Keterbatasan studi kami adalah adanya kemungkinan bias recall dan bias pemilihan subjek. Informasi mengenai riwayat atopi keluarga didapatkan secara subjektif menurut ibu yang menjadi responden. Ibu yang memiliki anak dengan DA cenderung menyatakan adanya riwayat atopi pada keluarga. Selain itu, sebagian besar subjek berasal dari status ekonomi menengah ke atas dengan tingkat pendidikan ibu yang tinggi sehingga tidak dapat menggambarkan populasi keluarga di Indonesia pada umumnya.

\section{Kesimpulan}

Penelitian kami belum dapat membuktikan manfaat pemberian ASI eksklusif untuk mencegah kejadian DA pada anak. Pada anak dengan riwayat atopi keluarga, pemberian ASI eksklusif cenderung memiliki efek proteksi, tetapi tidak bermakna secara statistik. Pemberian ASI eksklusif masih sangat direkomendasikan karena memiliki banyak manfaat dan keunggulan dibandingkan susu formula.

\section{Daftar pustaka}

1. Correale CE, Walker C, Murphy L, Craig TJ. Atopic dermatitis: a review of diagnosis and treatment. Am Fam Physician 1999;60:1191-8.

2. Horii KA, Simon SD, Liu DY, Sharma V. Atopic dermatitis in children in the United States, 1997-2004: visit trends, patient and provider characteristics and prescribing patterns. Pediatrics 2007;120:527-34.

3. Knoell KA, Greer KE. Atopic dermatitis. Pediatr Rev 1999;20:46-52.

4. Leung DYM, Boguniewicz M, Howell MD, Nomura I, Hamid QA. New insights into atopic dermatitis. J Clin Invest 2004;113:651-7.

5. Leung DYM. Atopic dermatitis. Dalam: Leung DYM, Sampson HA, Geha RS, Szefler SJ, penyunting. Pediatric allergy: principles and practice. Edisi ke-6. Philadelphia: Mosby;2003. h. 561-71.

6. Eichenfield LF, Hanifin JM, Lugen TA, Stevens SR, Pride $\mathrm{HB}$. Consensus conference of pediatric atopic dermatitis. J Am Acad Dermatol 2003;49:1088-95.

7. Miyake Y, Tanaka K, Sasaki S, Kiyohara C, Ohya Y, Fukushima W, dkk. Breastfeeding and atopic eczema in Japanese infants: The Osaka Maternal and Child Health Study. Pediatr Allergy Immunol 2009;20:234-41.

8. Oranje AP, de Waard-van der Spek FB. Atopic dermatitis: review 2000 to January 2001. Curr Opin Pediatr 2002;14:410-3.

9. Williams HC. Epidemiology of atopic dermatitis. Clin Exp Dermatol 2000;25:522-9.

10. Williams H, Robertson C, Stewart A. Worldwide variations in the prevalence of symptomps of atopic eczema in the International Study of Asthma and 
Allergies in Childhood. J Allergy Clin Immunol 1999;103:125-38.

11. Munasir Z, Sastroasmoro S, Djauzi S, Waspadji S, Ramelan W, Aminullah A, dkk. The role of allergic risk and other factors that affect the occurence of atopic dermatitis in the first 6 months of life. Asia Pac Allergy 2011;1:73-9.

12. Kim JS. Pediatric atopic dermatitis: the important of food allergens. Semin Cutan Med Surg 2008;27:156-60.

13. Van der Hulst AE, Klip H, Brand PL. Risk of developing asthma in young children with atopic eczema: a systematic review. J Allergy Clin Immunol 2007;120:565-9.

14. Krakowski AC, Eichenfield LF, Dohil MA. Management of atopic dermatitis in the pediatric population. Pediatrics 2008;122:812-24.

15. Sears MR, Greene JM, Willan AR, Taylor DR, Flannery EM, Cowan JO, dkk. Long-term relation between breastfeeding and development of atopy and asthma in children and young adults: a longitudinal study. Lancet 2002;360:901-7.

16. Abbas AK, Lichtman AH. Hypersensitivity. Dalam: Basic immunology: functions and disorders of the immune system. Edisi ke-3. Philadelphia:Saunders;2009. h.20521.

17. Santosa H. Dermatitis atopi. Dalam: Akib AAP, Munasir Z, Kurniati N, penyunting. Buku ajar alergi-imunologi anak. Edisi ke-2. Jakarta: Balai Penerbit IDAI;2007. h.234-44.

18. Galli E, Cicconi R, Rossi P, Casati A, Brunetti E, Mancino G. Atopic dermatitis: molecular mechanisms, clinical aspects and new therapeutical approaches. Current Molecular Medicine 2003;3:127-38.

19. Rance F, Boguniewicz M, Lau S. New visions for atopic eczema: An iPAC summary and future trends. Pediatr Allergy Immunol 2008;19:17-25.

20. Weideinger S, Illig T, Baurecht H. Loss-of-function variations within the filaggrin gene predispose for atopic dermatitis with allergic sensitizations. J Allergy Clin Immunol 2006;118:214-9.

21. Hanifin JM, Rajka G. Diagnostic features of atopic dermatitis. Acta Derm Venereol 1980;92:44-7.

22. De D, Kanwar AJ, Handa S. Comparative efficacy of Hanifin and Rajka criteriaand the UK working party criteria in diagnosis of atopic dermatitis in a hospital setting in North India. J Eur Acad Dermatol Venereol 2006;20:853-9.

23. Burks AW, Jones SM, Boyce JA, Sicherer SH, Wood RA, Assa'ad A, dkk. NIAID-sponsored 2010 Guidelines for managing food allergy: application in the pediatric population. Pediatrics 2011;128:955-65.

24. Sampson HA. The evaluation and management of food allergy in atopic dermatitis. Clinics in Dermatology 2003;21:183-92.

25. Grulee CG, Sanford HN. The influence of breast and artificial feeding on infantile eczema. J Pediatr 1936;9:223-5.

26. Djunaedi T. Manfaat pemberian ASI eksklusif minimal sampai 4 bulan terhadap kejadian dermatitis atopi pada bayi berusia 6-12 bulan pengunjung unit rawat jalan anak RSUP Dr. Hasan Sadikin Bandung 1998. Tesis. Bandung: Fakultas Kedokteran Program Pendidikan Dokter Spesiali Ilmu Kesehatan Anak Universitas Padjajaran, 1998.

27. M'Rabet, Vos AP, Boehm G, Garssen J. Breast-feeding and its role in early development of the immune system in infants:consequences for health later in life. J Nutr 2008;138:1782-90.

28. Munasir Z, Kurniati N. Air susu ibu dan kekebalan tubuh. Dalam: Ikatan Dokter Anak Indonesia Cabang Daerah Khusus Ibukota Jakarta. Hegar B, Suradi R, Hendarto A, Partiwi IGA, penyuntng. Bedah asi, kajian dari berbagai sudut pandang ilmiah. Jakarta: Balai Penerbit Fakultas Kedokteran Universitas Indonesia;2008. h. 69-81.

29. Hanson LA, Sifverdal SA, Stromback L, Erling V, Zaman $S$, Olcen P, dkk. The immunological role of breast feeding. Pediatr Allergy Immuno. 2001;12:15-9.

30. Isolauri E, Kalliomaki M, Laitinen K, Salminen S. Modulation of the maturing gut barrier and microbiota: a novel target in allergic disease. Current Pharmaceutical Design 2008;14:1368-75.

31. Jackson KM, Nazar AM. Breatfeeding, the immune response, and long-term health. J Am Osteopath Assoc 2006;106:203-7.

32. Kalliomaki M, Salminen S, Arvilommi H, Kero P, Koskinen P, Isolauri E. Probiotics in primary intervention of atopic disease: a randomised placebo-controlled trial. Lancet 2001;357:1076-9.

33. Calder PC, Krauss-Etschmann S, de-Jong EC, Dupont C, Frick JS, Frokiaer H, dkk. Early nutrition and immunityprogress and perspectives. Br J Nutr 2006;96:774-90.

34. Kalliomaki M, Ouwehand A, Arvilommi H, Kero P, Isolauri E. Transforming growth factor- $\beta$ in breast milk: A potential regulator of atopic disease at an early age. $\mathrm{J}$ Allergy Clin Immunol 1999;104:1251-7.

35. Hoppu U, Kalliomaki M, Laiho K, Isolauri E. Breast milk-immunomodulatory signals against allergic diseases. Allergy 2001;56:23-36.

36. Kull I, Bohme M, Wahlgren CF, Lennart N, Pershagen 
G, Wickman M, dkk. Breastfeeding reduces the risk for childhood aczema. J Allergy Clin Immunol 2005;116: 657-61.

37. Gdavelich M, Mimouoni D, David M, Mimouoni M. Breastfeeding and the onset atopic and dermatitis in childhood: a systemic review and meta-analysis of prospective studies. J Am Acad Dermatol. 2001;45:520-7.

38. Ghaderi R, Makhmalbat Z. Effect of breast-feeding on the development of atopic dermatitis. Ir J Allergy Asthm Immunol 2005;4:129-32.

39. Greer FR, Sicherer SH, Burrks AW. Effects of early nutritional interventions on the development of atopic disease in infants and children: the role of maternal dietary restriction, breastfeeding, timing of introduction of complementary foods, and hydrolyzed formulas. Pediatrics 2008;121:183-9.

40. Kajosaari M. Atopy prevention of childhood: the role of diet. Prospective 5-year follow-up of high-risk infants with six months exclusive breastfeeding and solid food elimination. Pediatr Allergy Immunol 1994;5:26-8.

41. Kramer MS, Chalmers B, Hodnett ED, Sevkovskaya Z, Dzikovich I, Shapiro S, dkk. Promotion of breastfeeding intervention trial (PROBIT), a randomized trial in the Republic of Belarus. JAMA 2001;285:413-20.

42. Kramer MS. Breatfeeding and allergy. Ann Nutr Metab 2011;59:20-6.

43. Kull I, Wickman M, Lilja G, Nordvall SL, Pershagen G. Breastfeeding and allergic diseases in infants-a prospective birth cohort study. Arch Dis Child 2002;87:478-81.

44. Laubereau B, Brockow I, Zirngibl A, Koletzko S, Gruebl A, Berg AV, dkk. Effect of breast-feeding on the development of atopic dermatitis during the first 3 years of life-results from the GINI-birth cohort study. J Pediatr 2004; 144:602-7.

45. Ludvigsson JF, Mostrom M, Ludvigsson J, Duchen K. Exclusive breastfeeding and risk of atopic dermatitis in some 8300 infants. Pediatr Allergy Immunol 2005;16:201-8.

46. Yang YW, Tsai CL, Lu CY. Exclusive breastfeeding and incident atopic dermatitis in childhood: a systematic review and meta-analysis of prospective cohort studies. British J Dermatol 2009;161:373-83.
47. Benn CS, Wohlfahrt J, Aaby P, Westergaard T, Benfeldt E, Michaelsen KF, dkk. Breastfeeding and risk of atopic dermatitis, by parental history of allergy, during the first 18 months of life. Am J Epidemiol 2004;160:217-23.

48. Bergmann RL, Diepgen TL, Kuss O, Bergmann KE, Kujat J, Dudenhausen JW, dkk. Breastfeeding duration is a risk factor for atopic eczema. Clin Exp Allergy 2002;32:205-9.

49. Purvis DJ, Thompson JMD, Clark PM, Robinson E, Black PN, Wild JJ, dkk. Risk factor for dermatitis in New Zealand children at 3-5 years of age. Br J Dermatol 2005;152:742-9.

50. Pohlabeln H, Muhlenbruch K, Jacobs S, Bohmann H. Frequency of allergic disease in 2-year-old children in relationship to parental history of allergy and breastfeeding. J Investig Allergol Clin Immunol 2010;20:195-200.

51. Siltanen M, Kajosaari M, Poussa T, Saarinen KM, Savilahti E. A dual long-term effect of breastfeeding on atopy in relation to heredity in children at 4 years of age. Allergy 2003;58:524-30.

52. Kilpi T, Kero J, Jokinen J, Syrjanen R, Takala AK, Hovi $\mathrm{T}$, dkk. Common respiratory infections early in life may reduce the risk of atopic dermatitis. Clin Infect Dis 2002;34:620-6.

53. Bottcher MF, Jenmalm MC, Bjorksten B. Cytokine, chemokine and secretory IgA levels in human milk in relation to atopic disease and IgA production in infants. Pediatr Allergy Immunol 2003;14:35-41.

54. Duchen K, Casas R, Fageras-Bottcher M, Yu G, Bjorksten B. Human milk polyunsaturated long-chain fatty acids and secretory immunoglobulin A antibodies and early childhood allergy. Pediatr Allergy Immunol 2000;11:2939.

55. Laiho K, Lampi AM, Hamalainen M, Moilanen E, Piironen V, Arvola T, dkk. Breast milk fatty acids, eicosanoids and cytokines in mothers with and without allergic disease. Pediatr Res 2003;53:642-7.

56. Wijga AH, Houwelingen ACV, Kerkhof M, Tabak C, Jongste JCD, Gerritsen J, dkk. Breast milk fatty acids and allergic disease in preschool children: the prevention and incidence of asthma and mite allergy birth cohort study. J Allergy Clin Immunol 2006;117:440-7. 